\title{
Facing Cross Border: The Protection for Undertakings and Social Welfare in Indonesia
}

\author{
Ria Setyawati ${ }^{1}$ Irena Sasty Audila ${ }^{2}$ \\ \{ setyawati.ria@gmail.com ${ }^{1}$, irena.sasty-13@ fh.unair.ac.id ${ }^{2}$ \} \\ Universitas Airlangga, 1. Airlangga No.4 - 6, Airlangga, Gubeng, Kota Surabaya, JawaTimur 60115, \\ Indonesia
}

\begin{abstract}
Law Number 5 of 1999 on Prohibition of Monopolistic Practices and Unfair Competition (hereafter referred to as Law No. 5/1999), has governed the exhausted list of concerted practices which also known as the list of prohibited agreement on competition law. One form of the prohibited agreement is the so-called cartel. Cartel is regulated under Article 11 of Law No. 5/1999. The Commission of Supervision on Business Competition (KPPU in Indonesia) has handled the cartel case since the Commission was established in 1999. From several cartel cases, none of the cases have been linked to the cross-border cartel. The cross-border cartel is a real threat that KPPU must face for the welfare of domestic undertakings. Legal protection against cross-border cartel behavior is needed, not only for undertakings in a relevant market but also for social welfare. For national cartels, there are many obstacles that KPPU has to handle. Searching some adequate evidence for cartel agreements is one of the significant obstacles that KPPU has to solve. For cross-border cartel activity, the obstacles are more complex. Before KPPU facing any case of the crossborder cartel, it is essential to give an analysis about how Article 11 of Law No. 5/1999 can approach cross-border cartel cases. The second legal issue is examining what kind of legal remedies can be taken in a cross-border cartel case.
\end{abstract}

Keywords: Cartel Regulation, Commission of Supervision on Business Competition, Cross-Border Regulation

\section{Introduction}

An ideal educational setting a class is not only seen as a group of people gaining lesson from a real figure only, but they also possess psychic. In that part then the teacher mentors the existing psychic in a process called education. There are different desires and objectives to achieve. So they are not only gathering and lining up. A class needs to be managed well. The presence of teachers becomes the key to better classroom management so that teachers need to convey material with appropriate methods. Before arriving at the part of the method, the strategy applied should also be considered following the method to be selected. The precision between the two will be an intermediary so that the delivered teaching materials will be understood by the students.

The purpose of fair competition, as stated in Article 3 of Law No. 5/1999, is to: a. Maintain public interest and improve the efficiency of the national economy as one of the means to improve public welfare. The improvement of people's welfare in the Article 3 letter (a) of Law No. 5/1999 has the purpose of manifesting fair competition. The enactment of Law No. 5/1999 is intended to provide legal certainty and equal protection to every undertaking in running their business, by preventing the emergence of monopolistic practices and other unfair 
competition with intention to create the conducive business climate. Conducive business climate generates fair competition for undertakings. Cartel cases in Indonesia are only involving undertakings that legally domiciled in Indonesia and those conducting economic activities within Indonesia's territory. The damages arising from the cartel's behavior are real and profoundly experienced not only by undertakings which do not participate in cartel agreements but also by society. In the current era of globalization, market openness cannot be avoided. Indonesian legal instruments must be ready to face the cross-border cartel forms in order to protect domestic undertakings and social welfare.

The existence of cross-border cartel has injured people's welfare and other undertakings to be developed in the relevant market within Indonesia's territory. From these backgrounds, there are two legal issues to be discussed in this paper, namely, whether cross-border cartel falls within the scope of protection related to the cartel that has been regulated in the Article 11 of Law No. 5/1999 and what are the legal remedies that can be exercised by domestic undertakings in facing cross-border cartel.

\section{Methodology}

The method using normative juridical by comparing the regulations in Indonesia with some countries. The data analyzed in perspective descriptive method.

\section{Cross-Border Cartel In Definition}

Anatomizing the legal rules of the cross-border cartel in the Law No. 5/1999 requires a deep understanding of cartels and the definition of the cross-border cartel. Hereafter, it is necessary to examine the possibility of the applicability of articles related to the cartel in Law No. 5/1999. Writing method to examine the first legal research is using the normative legal approach. To analyze further, a juridical and conceptual approach is used. The other legal research about the legal remedies to overcome cross-border cartel practice applies similar approaches to analysis description of the first legal research, with the addition of the case approach.

One of the prohibited agreements based on the Law No. 5/1999 is cartel agreement. Cartelis a conspiracy or partnership between several producers of similar products to control production, prices, and sales to obtain a monopoly position[1]. The cartel's terms can be found in several languages such as "cartel" in English and "Kartel" in Dutch. The cartel is also called "syndicate" which is an agreement (written or oral) between several producing companies and others to regulate and control various things, such as price, marketing area, and so on, to suppress competition within the relevant market and make profits[2].

In the Article 11 of Law No. 5/1999, the cartel can be examined throughout three things, namely by price, production, and marketing area. Cartels are formed by cartels by setting prices for products or services. Production cartelist a cartel behavior in controlling the supply of products by agreeing on both the quality and quantity of cartelist's goods and services. Meanwhile, the agreement made by the cartels in the form of specific marketing strategies, including the marketing area, is also one of the cartel's forms.

There are two kinds of cartels that might take place, videlicet[3]:

1. The occurrence of monopolistic practices by cartel actors inflicting a macro inefficiency of resource allocation, which result in the deadweight loss or loss of weight that is generally caused by the restriction of production policy produced by monopolistic enterprises to 
keep the prices high.

2. In terms of consumers, will lose the choice of price, competitive quality, and goods aftersales service.

In industry, if there are only a few players who dominate the market, the situation will encourage them to increase profits and limit production levels. This is performed to evade serious competition for each undertaking, so that it may increase benefits, market division, and set prices. In practice, this activity is usually manifested in the form of association. As members of the association, undertakings may agree on fixing prices, area division, or level of production, which then create monopolistic practices and unfair competition. Such trade practice may cause losses to consumers due to the limited quantity of goods in the market, and there may be significant price changes or high prices for a product. Cartel practice will allow producers to raise the price of goods according to their will. This may create an obstacle for potential competitors to enter the market. As for consumers, the selection of goods and services will be restricted in a relevant market.

Another example of cartels is that suppliers manage a single sales agent who buys all of their output at an agreed price and arranges coordinated rules to market the products. Another form is, the suppliers agree by fixing the selling price for their product, thus eliminating price competition, but competing to seize market division with a product differentiation strategy. A more comprehensive cartel form is the application, not just the uniform of selling price and shared market, but also the delimitation of production quantities including the use of quota systems for each supplier, and coordinated capacity adjustment, whether to omit excessive capacity or to expand capacity by coordination. Cartels are usually done either to utilize the joint market forces of the suppliers to gain monopoly advantages, as well as to defend against the real competition[3].

The cross-border cartel has no specific definition. When associated with the foreign market, the cartel that is originally a domestic anti-competitive activity will turn into a transnational anti-competitive action that is detrimental to a particular country. This type of cartel will then refer to the term of the cross-border cartel, which is a form of cartel activity conducted by undertakings in a particular country, which then negatively impacts undertakings of another country and even influences the consumers' welfare outside the country's territory.

Cross-border is defined as "Passing, occurring, or performing across a border between two countries"[4]. This definition can be interpreted as something which happens beyond the border of two states. In a broader sense, cross-border can be interpreted as an activity that occurs between different countries or involves people from more than one country[5][6]. When it comes to legal practice, cross-border can be understood as something that goes beyond the jurisdiction of a country, related to other countries[7].

The cross-border cartel has the same meaning as the cartel in general. The territory covered by the cartel is one domestic territory in which the undertakings whose performing cartel come from, but for the cross-border cartel, the territory of the cartel's behavior will be interpreted not only in one jurisdiction but also related to other jurisdiction of the country concerned.

The cross-border cartel can be understood as an anti-competitive activity carried out by undertakings originated from a country, or undertakings from several different countries, to control the amount of production and price so it may affect the market outside the territory of a country where the undertaking is originated. The types of cross-border cartel are not different from those conducted within a national border. The only thing that distinguishes it is the international dimension of a cartel's behavior. The exercise of the cross-border cartel may 
have negative influences on the relationship of countries whose involve in cartel and countries affected by cartel activities. This may dilute fair competitions in the global market and disable the competitiveness of competitors that are not incorporated in cartels.

\section{Cartel Under Indonesia Competition Law}

The uncovered cartel cases in Indonesia that have been terminated by the Supervision of Business Competition in Indonesia (KomisiPengawasPersaingan Usaha, hereafter referred as KPPU) are the behavior of undertakings that adversely affect the society up to trillion rupiahs, although the cartel's conduct is sometimes only less than three months. As an example, the case of garlic cartel that has been decided by KPPU in 2015, causing losses up to 1.7 trillion rupiahs in just ten weeks. In addition to the case of garlic cartel, KPPU has also succeeded in investigating the tires of four-wheel vehicles cartel and production arrangements of broiler breeding.

The cartel cases that have been decided by KPPU, heretofore, only compromising undertakings which are legally domiciled in Indonesia and those are conducting economic activities within Indonesia's territory[8]. Detriments arising from cartel's behavior are tangible and have been experienced not only for undertakings which do not participate in cartel agreements but also Indonesian citizens. In the current era of globalization, market openness cannot be avoided. Indonesian legal instruments shall be prepared to encounter the crossborder cartel form in order to protect domestic undertakings [3].

Cross-border cartel from its subject is a cartel behavior encompassing undertakings from different countries. Those undertakings are performing economic activities outside of the country where their companies have been established. Cross-border cartel involves the export and import of goods and services. The cross-border cartel is also known as the export cartel. Export cartel, nowadays, is rapidly growing in countries with frail protection of competition policy[9]. Export cartel actors are usually choosing another country to conduct cartel activity so that it will not affect disadvantageous the welfare of the country of origin. Another reason for the cross-border cartel is to get maximum profits that are received from the distribution of goods and services in a broader geographic market and eliminates competition. Cross-border cartel actors consciously notice that competition authorities are facing difficulty to catch them.

In 2015, KPPU made a decision on the procurement of imported cattle cartel in Jakarta, Bogor, Depok, Tangerang, and Bekasi (Case Number 10/KPPU-I/2015). All of the actors subject to sanctions are domestic undertaking whereas imported cattle cartel cannot be exempted from undertakings conducting exports. It is alleged that only cattle from Australia get permission to enter the cattle market in Indonesia in order to fulfill the quota of society's demand. It is unlikely that a cartel-related to imported cattle does not involve undertakings from an exporting country. However, KPPU only is able to carry actions against domestic undertakings.

\section{Strategies To Facing Cross Border Cartels}

In the digital era, the cross-border cartel has been conducted by trading through the online marketplace. The recent development in the United States and Europe from the online marketplace presently, is that the undertakings create their online marketplace without going through available free websites. This phenomenon is originated from automotive suppliers, obiter, General Motors Corp., Ford Motor Co., Daimler Chrysler A.G., Renauld S.A., and 
Nissan Motor Co. Ltd., joined the online B2B marketplace called "Covisint". The case of cross-border cartel through online media that have occurred in 2001.

One of the barriers to handle cartel cases is because cartels are difficult to be proven. This obstacle motivates countries to establish a system to facilitate cartel's verifications. Leniency program was first introduced by the United States (US) in 1973 and began to had an impact after the revision of the Corporate Leniency Program in 1993[10]. Leniency program then became more thrived after being introduced by the Department of Justice - Antitrust Division (DOJ-AD) in the US in 1978. At that moment, the leniency program is a system that has been adopted in many countries as a method to perform a faster and easier legal enforcement of cartel behaviors.

Leniency program is defined as "a system, publicly announcement, of, partial or total exoneration from the penalties that would otherwise apply to a cartel member, which reports its cartel membership to a competition (law) enforcement agency"[11]. This definition is defined as an amnesty system exonerating cartel members who denounce cartel practices to the competition authority, which may be formed as a partial or full liberation of the penalty or fines that shall be applied. In short, a leniency program is a system that can be executed by National Competition Authorities (NCA) of a country to eradicate cartels. Leniency program works to give remission of fines and punishment for cartel actors if they acknowledge committing such cartel activity. Not only ethereality, but leniency program may also provide immunity to the reported undertakings if the activities are conducted in groups. Leniency program as an essential method to handle cartel cases is not yet applied in Indonesia.

Current law enforcement related to the cartel is taken with the recognition of indirect evidence. KPPU in deciding a case, using two approaches, namely, juridical approach and economical approach. Case analysis conducted by KPPU by using economic approach is a realization of KPPU's attempt to figure the presence of indirect evidence. The good news is, although not recognized by positive law related to legal evidence in Indonesia, the judge in deciding cases related to Indonesian competition law may still receive indirect evidence.

In addition to the difficulties of KPPU to find evidence in cartel cases, KPPU also faces restrictions in Law No. 5/1999 to determine which parties are accountable for anti-competitive behavior. The Article 3 Letter (c) of Law No. 5/1999 stipulates the scope of anti-competitive behavior is undertaking. Furthermore, Article 1 (5) of Law No. 5/1999 provides an understanding of undertakings. In this article, the undertaking is a person or a company, in the form of a legal or non-legal entity established and domiciled or engaged in activities within the legal territory of the Republic of Indonesia, conducting various kinds of business activities in economic sector through contracts, both individually and collectively. The definition of undertakings in the article shows that KPPU has no chance to ensnare undertakings from the outside of Indonesia's territory who engage in the anti-competitive activity. For that matter, there is a solution to the clause of conducting business within Indonesia's territory. This clause allows KPPU to entrap foreign undertakings that are performing the unfair competition in Indonesia.

The application of the definition of the undertaking under Article 1 (5) of Law No. $5 / 1999$, will be difficult to be applied for cross-border cartel behaviors. Cross-border cartel actors shall be undertakings that are establishing companies outside of Indonesia's territory, legally domiciled outside Indonesia and conducting business above Indonesian borders. For instance, we are talking about the cross-border cartel in the online marketplace as in the case of Covisint, or the involvement of foreign companies from exporting countries in the case of imported cattle cartel in Indonesia. These cartel behaviors are dealing with undertakings coming from outside Indonesia's territory but affecting the domestic market, although the 
business activity is not conducted in Indonesia. The impact of cross-border cartel does not differ from the cartel that is only committed by domestic actors.

The legal aperture of Article 1 (5) related to the definition of undertakings has revised Law No. 5/1999 is necessary. The scope of the definition of the undertaking must be able to reach undertakings from outside Indonesia who are involved in the cross-border cartel, impacting the domestic market and people's welfare.

The regulation of the cartel in the Article 11 of Law No. 5/1999 has elements entailed to be filled in order to categorize a form of cartel agreement as one of anti-competition behavior, these elements are: cartel behavior performed by more than one undertaking, there is an agreement, there must be competition between undertakings involving in the cartel, restricting the production, influencing prices, managing the marketing area, and distributing consumers. The last ingredient is that cartel events can lead to monopoly and unfair competition.

Article 11 of Law No. 5/1999 may ensnare the cartel actors in the relevant market. The availability of Article 11 of Law No. 5/1999 has become a primary ground by KPPU to execute cartel cases in Indonesia. The only drawback is that Article 11 of Law No. 5/1999 cannot be enforced to foreign undertakings which performed cross-border cartel activity and impairing domestic market.

After reviewing the enforcement of the articles relating to the cartel in Law No. 5/1999, there is still a lack of legal certainty related to cross-border cartel cases. Obstacles faced by the cross-border cartel are a matter of state jurisdiction in international law. Foreign undertakings involved in cross-border cartel behavior is not the subject of Indonesian competition law. To resolve these jurisdictional barriers, there are two solutions, the first is the application of comity principle, and the second is bilateral cooperation.

One of the completions is to apply the comity principle, which has been known in international law. Comity doctrine was first developed in the Netherlands at the end of the 17 th century. This doctrine was raised to provide a win-win solution between the sovereignty of the state's territory and the interests of international trade[12].

Ulrik Huber, as one of the pioneers of comity doctrine, gives the approach that comity is "Exempla, quibusutemur, ad jurisprivati species maximequidempertinebunt, sedjudicium de illisunicejurispublicirationibusconstat, \&exindedefiniridebent." Ulrik Huber explained that comity is an example that should be used as a principle in the category of private law, but the treatment given is based exclusively on the principles of public law and must be determined by applicable regulations. This definition can be defined briefly as comitasgentium or civility of the nation, which is a justification to apply foreign law in a country[12].

Comity is a legal principle whereby political entities, such as the state or courts of jurisdiction, recognize legislative, executive, and judicial powers of other jurisdictions (Legal Informative Institute)[13]. The idea underlying is that a country will have to respect the decision made by the court of another country. Comity principle has two forms, namely Positive Comity and Negative Comity.

Positive comity means that aggrieved countries may apply to another country[14]. In the case of a cross-border cartel, the country affected by the cartel's action may apply to the country where the offending undertaking is originated. This petition may even be submitted before a country is harmed; the tendency for expected losses is sufficient to propose the positive comity principle. Positive comity encourages the state to be vital in enforcing competition law. There will be no confusion as to which state's jurisdiction will be used in the case of a cross-border cartel since in resolving the cartel case that arises, the policy that is exercised is the legal product of the country where cartel actors are originated. Positive comity is a reliable solution as an alternative dispute resolution of cross-border cartel cases, but the 
effectiveness is limited. Positive comity is only valid if the adverse violation does not only occur in the state which files the application but also has the potential to harm the country of origin of the anti-competitive action[15]. This is because, if the activity which creates damage in a particular country is not a violation in a country of origin, then the originated country has no reason to follow up the request.

Negative comity, on the other hand, is when another country refrains from enforcing its competition law if its legal application is contrary to the competition policy of other countries [13]. The noticeable difference between positive comity is that in this case, negative comity is more passive or shaped as self-defense. Negative comity is more related to all actions taken by a country to enforce the law by considering that it would not endanger other countries.

In the application of the comity principle, several conditions must be considered, namely:

1. A form of respect and goodwill to other countries.nComity principle is a principle in international law based on the good faith of the concerned country.

2. Conducted without coercion from other countries[13].This principle is implemented voluntarily as it relates to law enforcement within a state's territory[16].

3. Aims to protect the interests of other countries. This principle plays a vital role to protect the interests of other countries. Comity principle shows that the government is not solely concerned about the sustainability of its country, but also has the responsibility to uphold its legal products internationally[16].

4. An act of reciprocity. At least two states shall make the comity principle. Comity principle begins with a request from a country that feels aggrieved. However, the comity principle can also be directly exercised by a country without any request if the anti-competitive activity that has been performed hurts other countries.

5. The application of comity principle shall not be contrary to law in any state [14].

Comity principle should not conflict the law of its own country (Damien). Basically, the comity principle applies as a form to respect the interests of states that feel hazarded.

Comity principle can be utilized as a consideration of competition law enforcement entangled more than one country. In the case of a cross-border cartel, a country may apply its competition law to undertakings within its territory, even if the act committed by the undertaking has not disserved its own country, but disadvantageous the interests of another country. The core of the implementation of this principle is that the action taken by the undertaking is also prohibited by the law of the country of origin.

Also, to the application of the comity principle, another solution to consider is to exercise cooperation between countries. This form of cooperation is defined as two, namely, informal cooperation and formal cooperation.

Informal cooperation is a collaboration between government agencies, to share information such as sharing public information about competition law or policy and providing technical assistance. Indonesia has long applied this cooperation as part of the ASEAN Member States (AMS). For example, KPPU has conducted meetings with the NCA from most of AMSs to exchange ideas and solutions in encountering anti-competitive actions in their respective countries as well as at the regional level[17]. This meeting is not only dealing with solving cases but also projecting the direction and objectives of competition law in ASEAN.

The disadvantage of informal cooperation is that the meetings will only consist of discussion and exchange of information, but not producing a fixed legal product. However, this informal cooperation may still have its function in resolving the anti-competitive case that occurs, especially in the case of the cross-border cartel. Because it is not binding, this cooperation will ultimately refer to the good faith of a country to apply the understanding 
resulting from the meeting. As a harmonization solution, informal cooperation is a more natural way to be performed, though it does not always result in an adequate remedy.

The second type is formal cooperation. Formal cooperation involves signing agreements between the two countries. This bilateral agreement can be formed as either soft law or hard law[18]. Soft law agreement includes cooperation in sharing confidential information or requesting assistance from a partner country. On the other hand, hard law agreement incorporates with the enforcement of national laws from countries affected by anti-competitive actions such as cartel activity, to unlawful companies in contracting countries[19], [20]. In addition to this, hard law approach can also be a new legal form which in its implementation may change domestic legal products of the countries involved in the agreement. In this formal cooperation, hard law is interpreted as the binding agreement of two countries in order to settle an anti-competitive dispute that is undoubtedly using an individual policy that has been agreed to the agreement[21].

Hard law approach is an effective solution to punish business actors who are performing cross-border cartels. This approach contains an extraterritorial element, whereby, even though competition laws hold by two disputing countries which do not have the same legal standards or undertaking definitions, the existence of this agreement constitutes equalization and bond to countries in the agreement[22]. The existence of this bilateral agreement is answering the uncertainty of the jurisdiction of which country may apply the competition law to conquer anti-competitive cases. For now, none of AMD has agreed to establish a bilateral agreement, although there is an opportunity to do so.

\section{Conclusion}

There should be synchronized regulations to struggle the cross border cartel to facing the social welfare in Indonesia.

\section{References}

[1] J. Clarke, "The increasing criminalization of economic law - A competition law perspective," Journal of Financial Crime. 2011.

[2] R. Mantili, H. Kusmayanti, and A. Afriana, "Problematika Penegakan Hukum Persaingan Usaha di Indonesia dalam Rangka Menciptakan Kepastian Hukum," PADJADJARAN J. Ilmu Huk. (Journal Law), 2016.

[3] C. Leslie, "Antitrust amnesty, game theory, and cartel stability," J. Corp. Law, 2006.

[4] V. Bruno and H. S. Shin, "Cross-border banking and global liquidity," Rev. Econ. Stud., 2013.

[5] I. Erel, R. C. Liao, and M. S. Weisbach, "Determinants of Cross-Border Mergers and Acquisitions," J. Finance, 2012.

[6] K. Shimizu, M. A. Hitt, D. Vaidyanath, and V. Pisano, "Theoretical foundations of cross-border mergers and acquisitions: A review of current research and recommendations for the future," J. Int. Manag., 2004.

[7] R. Portes and H. Rey, "The determinants of cross-border equity flows," J. Int. Econ., 2005.

[8] W. Bank, Indonesia: The Challenges of World Bank Involvement in Forests. 2000.

[9] D. Slater and E. Simmons, "Coping by Colluding: Political Uncertainty and Promiscuous Powersharing in Indonesia and Bolivia," Comp. Polit. Stud., 2013.

[10] UNCTAD, "The use of leniency programmes as a tool for the enforcement of 
competition law against hardcore cartels in developing countries," in Sixth United Nations conference to review all aspects of the set of multilaterally agreed equitable principles and rules for the control of restrictive business practices, 2010.

[11] G. Hufbauer and J. Kim, "International Competition Policy and the WTO," Antitrust Bull., 2009.

[12] H. E. Yntema, "The Comity Doctrine," Mich. Law Rev., 1966.

[13] J. DAVIDOW, "The Sherman Act and Outward Bound Commerce," Georg. Mason Law Rev., 1998.

[14] F. M. Abbott, "Are the competition rules in the WTO agreement on Trade-Related apsects of intellectual property rights adequate? BT - Reforming the World Trading System: Legitimacy, Efficiency, and Democratic Governance," in Reforming the World Trading System: Legitimacy, Efficiency, and Democratic Governance, 2005.

[15] S. DeSANTI, "Riding the B2B Roller Coaster: The Study and Practice of Antitrust Laws in the New Economy," Georg. Mason Law Rev., 2001.

[16] D. Geradin, M. Reysen, and D. Henry, "Extraterritoriality, Comity, and Cooperation in EU Competition Law," in Cooperation, Comity, and Competition Policy, 2011.

[17] M. F. Hidayat, "POLITIK HUKUM PERSAINGAN USAHA DI INDONESIA," $J$. Cahaya Keadilan, 2017.

[18] K. Raustiala, "The Architecture of International Cooperation: Transgovernmental Networks and the Future of International Law," SSRN Electron. J., 2005.

[19] K. E. Maskus and M. Lahouel, "Competition policy and intellectual property rights in developing countries," World Econ., 2000.

[20] P. C. Mavroidis, G. A. Bermann, M. Wu, and World Trade Organization., The Law of the World Trade Organization (WTO): Documents, Cases \& Analysis. 2010.

[21] S. J. Evenett, M. C. Levenstein, and V. Y. Suslow, "International cartel enforcement: Lessons from the 1990s," World Econ., 2001.

[22] J. Drexl, "The transplantability of the EU's competition law framework into the ASEAN region," in The Regionalisation of Competition Law and Policy within the ASEAN Economic Community, 2018. 